\title{
Foresight Look on the Disinfection By-Products Formation
}

\author{
Djamel Ghernaout ${ }^{1,2 *}$, Noureddine Elboughdiri ${ }^{1,3}$ \\ ${ }^{1}$ Chemical Engineering Department, College of Engineering, University of Ha'il, Ha'il, Saudi Arabia \\ ${ }^{2}$ Chemical Engineering Department, Faculty of Engineering, University of Blida, Blida, Algeria \\ ${ }^{3}$ Département de Génie Chimique de Procédés, Laboratoire Modélisation, Analyse, et Commande des Systèmes, Ecole Nationale \\ d'Ingénieurs de Gabès (ENIG), Gabès, Tunisia \\ Email: ^djamel_andalus@hotmail.com
}

How to cite this paper: Ghernaout, D. and Elboughdiri, N. (2020) Foresight Look on the Disinfection By-Products Formation. Open Access Library Journal, 7: e6349. https://doi.org/10.4236/oalib.1106349

Received: April 23, 2020

Accepted: May 8, 2020

Published: May 11, 2020

Copyright () 2020 by author(s) and Open Access Library Inc.

This work is licensed under the Creative

Commons Attribution International

License (CC BY 4.0).

http://creativecommons.org/licenses/by/4.0/

(c) (i) Open Access

\begin{abstract}
In the water treatment industry, if there is a process that has attracted polemic discussion in terms of pros and cons disinfection has attracted the main part for its disinfection by-products (DBPs) formation. This work focuses on DBPs precursors, link among disinfection and DBPs, DBPs elimination, and study futures. During the last half-century, chlorination has been shown highly toxic to human health. Indeed, as a classical disinfectant, chlorine generates a bigger number of halogenated by-products than other disinfectants. Unfortunately, novel disinfection techniques and emerging pollutants in water can form fresh DBPs. DBPs surfacing lately are frequently with low levels and elevated poisoning. Further, as the oxidizing agent of the disinfectant increases, the formation of conventional DBPs is reduced, but more toxic DBPs emerge. Membrane processes, such as ultrafiltration and nanofiltration, depicted greater performance in eliminating organic matter if paralleled with traditional techniques. As a perspective, research should concentrate on physical processes such as distillation and/or solar disinfection, and filtration for better water treatment instead of injecting chemicals into water highly previously chemically polluted.
\end{abstract}

\section{Subject Areas \\ Chemical Engineering \& Technology}

\section{Keywords}

Disinfection, Disinfection By-Products (DBPs), Organic Matter (OM), Chlorination, Ozonation, Water Treatment 


\section{Introduction}

In the potable water treatment industry, disinfection has a key contribution to demobilizing pathogens in water [1] [2] [3] [4]. It considerably decreases the diffusion of various waterborne infectious diseases comprising typhoid and cholera, participating importantly in the safeguard of human health [5] [6] [7] [8]. Usual disinfection techniques comprise chlorination (chlorine and chloramines) [9] [10] [11], chlorine dioxide $\left(\mathrm{ClO}_{2}\right)$ [12] [13], ozonation [14], electrochemical advanced oxidation processes (AOPs) [15] [16] [17] [18] [19], and ultraviolet (UV) disinfection [20] [21] [22] [23]. More novel disinfection processes have also been suggested [24]-[31]. Nevertheless, the disinfection application is frequently joined by the generation of disinfection by-products (DBPs) which can induce additional public health troubles [32] [33] [34] [35].

DBPs were first proposed in 1974 [36] [37]. During water treatment, it was proved that chlorination can produce greatly toxic trihalomethanes (THMs) like chloroform [1] [12]. Further, high THMs concentrations in potable water were related to harmful reproductive outcomes [38]. Chlorination could generate additional poisonous DBPs like haloacetic acids (HAAs). Later, a bigger number of DBPs have been identified. Following chlorination or chloramination, haloamides, haloacetonitriles (HANs), and aldehydes also have been identified in drinking water [39] [40] [41]. In addition to chlorination, additional disinfection techniques also generate DBPs. The ozone disinfection method could form brominated organic and inorganic compounds (bromate, iodate, and chlorate) [42]. Among them, bromate is a suspected human carcinogen [43]. Brominated organic compounds like dibromoacetonitrile (DBAN) can also be produced throughout ozonation in the occurrence of high bromide levels [44], which could generate subchronic toxicity in rats [1]. UV disinfection could form nitrite if the water being treated holds nitrate [45].

This work focuses on the recent findings in DBPs precursors, link among disinfection and DBPs, DBPs elimination techniques, and study futures.

\section{DBPs Precursors}

DBPs precursors comprise both organic and inorganic matters and possess a fundamental contribution in generating such hazardous chemicals [1] [46] [47].

The main attention on precursors concentrated on natural organic matter (NOM), which is the primary organic precursor [1] [48] [49]. NOM was described as the complex matrix of organic material existing in natural water and possesses an evident impact on the disinfection process [50] [51] [52] [53]. It comprises humic substances [54] [55] [56] [57] and non-humic substances [58] [59] [60] [61] [62]. Humic substances are a crucial DBPs precursor and constitute an additional research interest [63]. The high molecular weight (MW) hydrophobic NOM fraction was more reactive with chlorine, while the low MW hydrophilic NOM fraction was more reactive to bromine and iodine [1] [63]. Fractionation of NOM depicted that the hydrophilic acid portion was the most 
reactive precursor for THMs, but least reactive for HAAs [1]. Further, $\mathrm{ClO}_{2}$ reacted with the humic fraction of NOM usually in the aromatic part of the molecule, and the carbonyls concentration considerably augmented with the reaction time between $\mathrm{ClO}_{2}$ and carbonyl precursors [1]. The chlorination of NOM led to increasing in assimilable organic carbon (AOC) production via the oxidation and chlorine substitution on aromatic molecules [10] [12]. AOC was useful to microbial growth, inducing a hazard to the biological safety of potable water [1] [49]. Moreover, NOM can generate high levels of poisonous aromatic DBPs which were afterward transformed into aliphatic DBPs during chlorination/ chloramination [1] [50] [52]. Traditional water treatment reduced most of the hydrophobic NOM with high MWs [63]. However, the low MW hydrophilic NOM was hard to remove, dominating residual organics [63]. Thus, it is fundamental to follow the reduction of the hydrophilic NOM part with low MW. AOPs [15] [31] [64] [65] [66] combined with biofiltration or biological activated carbon (BAC) [67] [68] [69] remains a more techno-economically practical choice to mineralize NOM [70].

Algogenic organic matter (AOM) [68] [71]-[76], a significant autochthonous organic derivative of algae, augmented the hazard of DBPs generation [77]. AOM was rich in nitrogen and protein; while, NOM was abundant in aromatic content [1]. Algae augmented dissolved (DON) in water and conducted to the augmentation of the possibility to form nitrogenous DBPs (N-DBPs) and other total organic halides (TOXs) [1]. In water, AOM could induce DBPs generation, taking up $20 \%-50 \%$ of the DBP formation potential (DBPFP) in usual treatment circumstances [1]. The origin of AOM was divided into extracellular organic matter (EOM) intracellular organic matter and (IOM). EOM and IOM of algae are known to participate in the production of DBPs. EOM and IOM were mostly classified in low-MW ( $<1 \mathrm{kDa})$ and high-MW ( $>100 \mathrm{kDa})$ portions, possessing a significant contribution in the generation of carbonaceous DBPs (C-DBPs) and N-DBPs in both chlorination and chloramination [1]. EOM and IOM conducted to the bigger production of N-DBPs and haloaldehydes than NOM throughout chlorination, while the quantity of N-DBPs and C-DBPs produced from chloramination of EOM and IOM was much less than that from NOM. Juxtaposed with EOM, IOM had a bigger portion of total organic nitrogen, larger proportions of higher MW compounds, more hydrophobic contents, as well as higher fractions of free amino acids but lower fractions of aliphatic amines [1].

Soluble microbial products (SMPs) are one more type of precursors that could give rise to more dichloroacetic acid (DCAA) and N-DBPs. Further, they possess a bigger DBPFP than NOM [1]. In an investigation on Chlorella sp., it was proved that with elevating algae cultivation time in wastewater, the collection of SMPs increased the production of DBPs and the trend of DBP generation was as follows: chloroform > DCAA > trichloroacetic acid (TA) [1]. The majority of identified N-DBP precursors tended to be of low MW and low electrostatic 
charge relative to most NOM. Consequently, it was not simple to eliminate them by traditional water treatment methods like coagulation [78] [79] [80] [81], while biodegradation and nanofiltration (NF) stay excellent options [82]-[87]. On the other hand, there were more contaminants from wastewater which may become DBPs precursors [7] [8] [88] [89] [90] [91] [92]. As an illustration, tertiary amine-containing pharmaceuticals or other quaternary amine-containing constituents of personal care products could work as N-nitrosodimethylamine (NDMA) precursors. A group of pharmaceuticals and personal care products (PPCPs) containing amine groups served as nitrosamine precursors during chloramine disinfection [93]. Moreover, phenols in raw water could lead to the generation of comparatively dangerous phenolic DBPs [57]. Biophysical and chemical processes also conduct to the formation of DBP precursors, leading to more DBPs generation in the reclaimed water [94] [95] [96] [97] [98].

The inorganic precursor bromide also magnetized awareness, as it conducted to the production of mixed bromochloro- and brominated DBP species throughout chlorination and chloramination [1]. Such chemicals are more carcinogenic and cytotoxic than their chlorinated counterparts [99] [100]. Bromide could be transformed into bromate throughout ozonation [100]. The occurrence of bromide also had an impact on the generation of iodo-DBPs (I-DBPs). As the reaction rate of $\mathrm{HOI}$ to $\mathrm{IO}_{3}^{-}$influenced the production of I-DBPs, pre-oxidation procedures with powerful oxidants like ozone and ferrate were employed for controlling I-DBPs [101].

\section{Link among Disinfection and DBPs}

As a classical disinfectant, chlorine generates a bigger number of halogenated by-products than other disinfectants [44]. THMs, HAAs, and halonitromethanes (HNMs) are mostly formed throughout the chlorination. Chlorine injection could also produce nitrosamines, HANs, aldehydes and some aromatic DBPs in the occurrence of particular precursors. Further, pre-oxidation via chlorine could lead to chlorate formation [42]. With a view to ameliorating disinfection, numerous disinfectants comprising ozone, $\mathrm{ClO}_{2}$, and chloramines have been utilized [1]. Implementing such agents diminishes the yield of the four regulated THMs, trihalogenated HAAs, and TOX; however, many priority DBPs produced from such chemicals could give rise to other troubles [102].

If juxtaposed with chlorination, chloramination usually forms lower levels of regulated DBPs [103]. However, chloramination could conduct to the generation of DBPs with greater toxicity, like HANs and HNMs, as well as NDMA, a kind of nitrosamine [104]. Furthermore, the fraction of Br-DBPs, which are more dangerous than their chlorinated analogs, was frequently bigger throughout chloramination than that throughout chlorination [105]. As a consequence, the formation of fresh DBPs has to be considered if substituting chlorine disinfection by chloramine [1].

Chlorine dioxide stays an efficacious disinfectant that forms fewer DBPs. 
THMs generated via $\mathrm{ClO}_{2}$ when juxtaposed to $\mathrm{Cl}_{2}$ [106]. Nevertheless, $\mathrm{ClO}_{2}$ conducts to the formation of HANs, aldehydes, and many inorganic DBPs like chlorites and chlorates. $\mathrm{ClO}_{2}$ is commonly integrated with chlorine disinfection; in this context, $\mathrm{ClO}_{2}$ oxidation prior to chlorination may decrease the generation of THMs and TOX [107]. However, in the occurrence of bromide, the part of $\mathrm{Br}$-DBPs augmented after $\mathrm{ClO}_{2} / \mathrm{Cl}_{2}$ pre-oxidation. The ratio of $\mathrm{ClO}_{2}$ has a considerable contribution to producing DBPs. With augmenting chlorine content in mixed oxidants, the generation of chlorite was diminished while more chlorate was produced. There is an optimum $\mathrm{ClO}_{2}$ : chlorine ratio which generates the smallest level of HANs and TCNM [108]. Consequently, it remains requested to set such a ratio following the water quality, so as to dominate the production of DBPs [1].

Ozonation could avert the formation of some DBPs [14]; however, pre-ozonation elevates the DBPFP of specific HAAs throughout coming chlorination [109]. If contrasted with chlorine disinfection, ozonation usually produced DBPs with bigger toxicity. Ozonation frequently formed carbonyl-containing by-products comprising aldehydes and short-chained carboxylic acids [1]. Further, bromate is produced by ozone in the existence of bromide. If ozonation is merged with BAC filtration, the generation of DBPs could be dominated to some extent via reducing precursors. BAC may efficiently decrease DBPFP, as well as the yields of DBPs such as N-nitrosamines, haloacetaldehydes (HALs), and haloacetamides (HAcAms), which were generated throughout ozonation [110] [111]. Taking into account the merits of this incorporation, $\mathrm{O}_{3} / \mathrm{BAC}$ could be utilized as an alternative disinfection method to chlorination [1] [12] [14].

In summary, as the oxidizing agent of the disinfectant increases, the formation of conventional DBPs is reduced, but more toxic DBPs emerge. When adopting the disinfection technique, it has to be considered with the particular water quality to decide if fresh DBPs may be given rise [1].

\section{DBPs Elimination}

For dominating DBPs, several techniques work on eliminating precursors such as coagulation, membrane filtration, AOPs, and their merged methods [1].

As the most frequent and economically realizable methods, coagulation and flocculation were employed to reduce NOM from potable water [1] [49] [51] [112]. However, more efficacious and economical technologies stay requested to eliminate both NOM and organic matter $(\mathrm{OM})$ due to water quality troubles [72] [81]. Many investigations have been dedicated to reducing DBP precursors by enhancing the action of coagulation [49] [50] [113]. Numerous fresh coagulants have been utilized in the water treatment industry [114] [115], like prehydrolyzed ferric and alum coagulants [116], $\mathrm{Mg} / \mathrm{Al}$ hydrotalcite, dendrimers, hyperbranched polymers, carbon nanotubes, and cyclodextrins [1] [117]-[123]. Further, the bromide level could be decreased efficiently via enhanced coagulation [49]. On the other hand, a few coagulants like chitosan can participate in 
producing N-DBPs [1].

Membrane processes depicted greater performance in eliminating NOM if paralleled with traditional techniques [85] [86] [87]. Membrane processes such as ultrafiltration (UF) and UF-nanofiltration (NF) can be efficacious in decreasing DBP precursors [124]. In addition, filtration could be integrated with ozonation to retain NOM [1].

For dealing with DBPs, AOPs involve ozonation, UV disinfection, oxidation with hydrogen peroxide $\left(\mathrm{H}_{2} \mathrm{O}_{2}\right)$, activated carbon and their integrations [33] [34] [35]. Vacuum ultraviolet (VUV, $185+254 \mathrm{~nm}$ ) reaches better performance than $\mathrm{UV}_{254}$ (only $254 \mathrm{~nm}$ ) in decomposing HANs [1] [23]. Many hybridizations of $\mathrm{UV}$ with additional treatment technologies are applied such as $\mathrm{UV}-\mathrm{H}_{2} \mathrm{O}_{2}$ founded AOP that was the most tried. $\mathrm{UV} / \mathrm{H}_{2} \mathrm{O}_{2}$ possesses the capability to dominate efficiently nitrosamines [125]. UV/ $\mathrm{H}_{2} \mathrm{O}_{2} /$ micro-aeration techniques are performant in decomposing totally DCAA [126]. When juxtaposed with a downstream BAC filter, the $\mathrm{UV} / \mathrm{H}_{2} \mathrm{O}_{2}$ method can reduce THM and HAAs formation greatly since BAC could efficaciously eliminate biodegradable DBPs [127]. UV may be also hybridized with $\mathrm{Cl}_{2}$. Indeed, $\mathrm{UV} / \mathrm{Cl}_{2}$ is more performant than $\mathrm{UV}$ alone in dealing with I-THM generation [1]. Fresh AOPs comprising UV/PS, UV/TiO 2 , UV/ $\mathrm{Cl}_{2}, \mathrm{TiO}_{2} / \mathrm{O}_{3}, \mathrm{O}_{3} / \mathrm{H}_{2} \mathrm{O}_{2}$, and $\mathrm{MnO}_{2} / \mathrm{O}_{3}$ have been implemented for dominating the production of DBPs [1].

\section{Study Futures}

Tang et al. [1] focused on the research trends in terms of three aspects: 1) analytical techniques; 2) toxicity and health effects; 3 ) water quality standards and control methods.

Figure 1 illustrates the first year in which each DBP species given in the keywords appear in the literature. Since the first publication concerning DBPs were released in 1974 [36] [37], novel categories of DBPs have constantly been detected until these days. As shown in Figure 1, DBPs found later usually have a tendency to be more poisonous than DBPs of primitive researches.

Novel disinfection techniques and emerging pollutants in water can form fresh DBPs [11] [88]. DBPs surfacing lately are frequently with low levels and elevated poisoning [1] [5] [7] [8] [89].

Due to the influences on human health, lower limits on numerous DBPs have been decided. Such regulated DBPs are mostly established following classical chlorination. However, employing different disinfectants (like chloramine, $\mathrm{ClO}_{2}$, and $\mathrm{O}_{3}$ ) conducts to the emergence of a fresh set of DBPs with worse poisoning, which are famous as unregulated DBPs [112]. It is vital to add hazardous emerging DBPs to the water quality standards, which can participate in attaining the target of rendering potable water safer. To satisfy the requirements of regulations, several types of research have been performed on dominating DBPs. DBPs dominating techniques are mostly incubated in two sides: enhancing disinfection engineering and pre-treatment techniques. As it forms a few DBPs, UV 


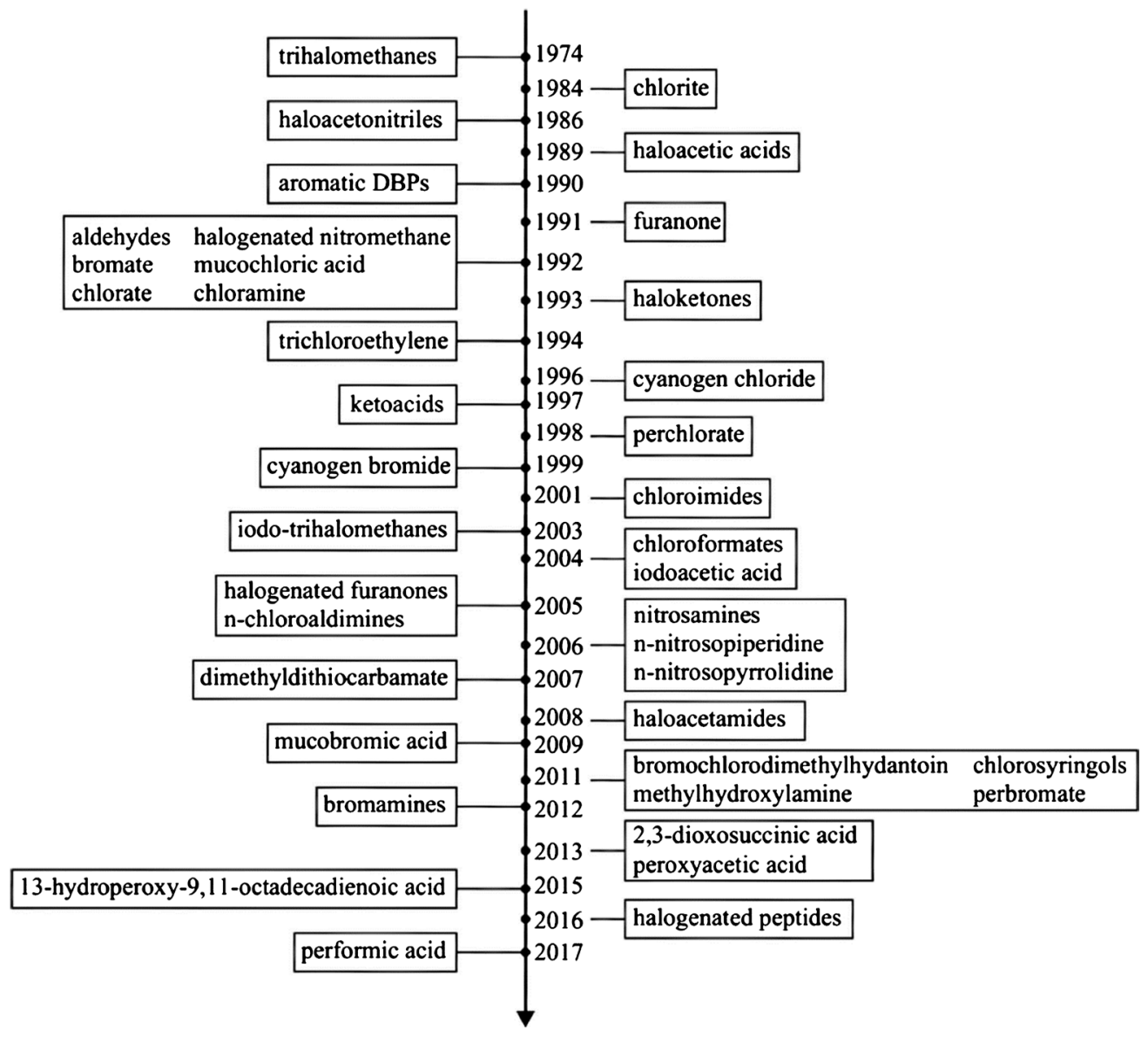

Figure 1. The historical review of DBPs from 1974 to 2018 [1].

disinfection is advocated to substitute classical disinfection processes. In addition, UV could be hybridized with ozonation. Indeed, Integrated $\mathrm{O}_{3}$-UV AOP is more performant than either ozone or UV treatment alone and is efficient in eliminating $\mathrm{OM}$ [23]. Additional integrated methods like $\mathrm{O}_{3} / \mathrm{BAC}$, permanganate oxidation, and powdered activated carbon adsorption (PM-PAC) were found efficient in dealing with DBPs [14]. Integrating diverse disinfection processes is viewed as a crucial choice to ameliorate disinfection engineering in the next years. Further, several fresh disinfection processes came out like solar disinfection via photocatalysis that is an encouraging technique possessing the capacity to eliminate both microorganisms and DBP precursors [68]. On the other hand, many nanomaterials could be utilized as disinfectants thanks to their antimicrobial characteristics and decrease the risk of grave DBPFP through the classical disinfection process [128]. Aside from enhancing disinfection engineering [129], it is more vital to eliminate DBPs precursors. Coagulation stays the most broadly implemented and economical treatment process [130]. AOP remains an encouraging technology for removing precursors, in which UV, $\mathrm{H}_{2} \mathrm{O}_{2}$, and $\mathrm{O}_{3}$ are employed commonly. Membrane processes should be adopted for safe potable water [15] [19] [64] [65] [118]. For distinct DBPs, several technologies may be merged to obtain satisfying elimination [1] [70] [131] [132]. 


\section{Conclusions}

In the water treatment industry, if there is a process that has attracted polemic discussion in terms of pros and cons disinfection has attracted the main part for its disinfection by-products formation. This work concerns DBPs precursors, link among disinfection and DBPs, DBPs elimination, and study futures. From this work, the main conclusions emerge.

During the last half-century, chlorination has been shown highly toxic to human health. Indeed, as a classical disinfectant, chlorine generates a bigger number of halogenated by-products than other disinfectants. Unfortunately, novel disinfection techniques and emerging pollutants in water can form fresh DBPs. DBPs surfacing lately are frequently with low levels and elevated poisoning. Further, as the oxidizing agent of the disinfectant increases, the formation of conventional DBPs is reduced, but more toxic DBPs emerge. Membrane processes, such as UF and NF, depicted greater performance in eliminating organic matter if paralleled with traditional techniques. As a perspective, research should concentrate on physical processes such as distillation, solar disinfection, and filtration for better water treatment instead of injecting chemicals into water previously highly-chemically polluted.

\section{Acknowledgements}

This research has been funded by the Research Deanship of University of Ha'il, Saudi Arabia, through the Project RG-191190.

\section{Conflicts of Interest}

The authors declare no conflicts of interest regarding the publication of this paper.

\section{References}

[1] Tang, Y., Long, X., Wu, M., Yang, S., Gao, N., Xu, B. and Dutta, S. (2020) Bibliometric Review of Research Trends on Disinfection By-Products in Drinking Water during 1975-2018. Separation and Purification Technology, 241, Article ID: 116741. https://doi.org/10.1016/j.seppur.2020.116741

[2] Ghernaout, D. and Ghernaout, B. (2010) From Chemical Disinfection to Electrodisinfection: The Obligatory Itinerary? Desalination and Water Treatment, 16, 156175. https://doi.org/10.5004/dwt.2010.1085

[3] Ghernaout, D. (2017) Environmental Principles in the Holy Koran and the Sayings of the Prophet Muhammad. American Journal of Environmental Protection, 6, 75-79. https://doi.org/10.11648/j.ajep.20170603.13

[4] Ghernaout, D. (2018) Disinfection and DBPs Removal in Drinking Water Treatment: A Perspective for a Green Technology. International Journal of Advances in Applied Sciences, 5, 108-117. https://doi.org/10.21833/ijaas.2018.02.018

[5] Ghernaout, D. and Elboughdiri, N. (2020) Should We Forbid the Consumption of Antibiotics to Stop the Spread of Resistances in Nature? Open Access Library Journal, 7, e6138. 
[6] Ghernaout, D. and Elboughdiri, N. (2020) On the Treatment Trains for Municipal Wastewater Reuse for Irrigation. Open Access Library Journal, 7, e6088. https://doi.org/10.4236/oalib.1106088

[7] Ghernaout, D. and Elboughdiri, N. (2020) Removing Antibiotic-Resistant Bacteria (ARB) Carrying Genes (ARGs): Challenges and Future Trends. Open Access Library Journal, 7, e6003. https://doi.org/10.4236/oalib.1106003

[8] Ghernaout, D. and Elboughdiri, N. (2020) Antibiotics Resistance in Water Mediums: Background, Facts, and Trends. Applied Engineering, 4, 1-6. https://doi.org/10.4236/oalib.1106003

[9] Ghernaout, D., Naceur, M.W. and Aouabed, A. (2011) On the Dependence of Chlorine By-Products Generated Species Formation of the Electrode Material and Applied Charge during Electrochemical Water Treatment. Desalination, 270, 9-22. https://doi.org/10.1016/j.desal.2011.01.010

[10] Ghernaout, D., Moulay, S., Ait Messaoudene, N., Aichouni, M., Naceur, M.W. and Boucherit, A. (2014) Coagulation and Chlorination of NOM and Algae in Water Treatment: A Review. International Journal of Environmental Monitoring and Analysis, 2, 23-34. https://doi.org/10.11648/j.ijema.s.2014020601.14

[11] Ghernaout, D. and Elboughdiri, N. (2020) Is Not It Time to Stop Using Chlorine for Treating Water? Open Access Library Journal, 7, e6007.

[12] Ghernaout, D. (2017) Water Treatment Chlorination: An Updated Mechanistic Insight Review. Chemistry Research Journal, 2, 125-138.

[13] Ghernaout, D., Alghamdi, A., Aichouni, M. and Touahmia, M. (2018) The Lethal Water Tri-Therapy: Chlorine, Alum, and Polyelectrolyte. World Journal of Applied Chemistry, 3, 65-71. https://doi.org/10.11648/j.wjac.20180302.14

[14] Ghernaout, D. and Elboughdiri, N. (2020) Towards Enhancing Ozone Diffusion for Water Disinfection-Short Notes. Open Access Library Journal, 7, e6253. https://doi.org/10.4236/oalib.1106253

[15] Ghernaout, D., Elboughdiri, N., Ghareba, S. and Salih, A. (2020) Electrochemical Advanced Oxidation Processes (EAOPs) for Disinfecting Water-Fresh Perspectives. Open Access Library Journal, 7, e6257. https://doi.org/10.4236/oalib.1106257

[16] Ghernaout, D., Elboughdiri, N., Ghareba, S. and Salih, A. (2020) Disinfecting Water with the Carbon Fiber-Based Flow-Through Electrode System (FES): Towards Axial Dispersion and Velocity Profile. Open Access Library Journal, 7, e6238. https://doi.org/10.4236/oalib.1106238

[17] Ghernaout, D., Touahmia, M. and Aichouni, M. (2019) Disinfecting Water: Electrocoagulation as an Efficient Process. Applied Engineering, 3, 1-12.

[18] Ghernaout, D. (2019) Greening Electrocoagulation Process for Disinfecting Water. Applied Engineering, 3, 27-31.

[19] Ghernaout, D. (2019) Electrocoagulation and Electrooxidation for Disinfecting Water: New Breakthroughs and Implied Mechanisms. Applied Engineering, 3, 125133.

[20] Ghernaout, D. and Elboughdiri, N. (2019) Electrocoagulation Process Intensification for Disinfecting Water-A Review. Applied Engineering, 3, 140-147.

[21] Ghernaout, D. and Elboughdiri, N. (2019) Iron Electrocoagulation Process for Disinfecting Water-A Review. Applied Engineering, 3, 154-158.

[22] Ghernaout, D. and Elboughdiri, N. (2020) Electrochemical Technology for Wastewater Treatment: Dares and Trends. Open Access Library Journal, 7, e6020.

[23] Ghernaout, D. and Elboughdiri, N. (2020) UV-C/ $\mathrm{H}_{2} \mathrm{O}_{2}$ and Sunlight $/ \mathrm{H}_{2} \mathrm{O}_{2}$ in the 
Core of the Best Available Technologies for Dealing with Present Dares in Domestic Wastewater Reuse. Open Access Library Journal, 7, e6161. https://doi.org/10.4236/oalib.1106161

[24] Ghernaout, D. (2017) Microorganisms' Electrochemical Disinfection Phenomena. EC Microbiology, 9, 160-169.

[25] Ghernaout, D., Aichouni, M. and Touahmia, M. (2019) Mechanistic Insight into Disinfection by Electrocoagulation-A Review. Desalination and Water Treatment, 141, 68-81. https://doi.org/10.5004/dwt.2019.23457

[26] Ghernaout, D., Alghamdi, A. and Ghernaout, B. (2019) Microorganisms' Killing: Chemical Disinfection vs. Electrodisinfection. Applied Engineering, 3, 13-19.

[27] Ghernaout, D. (2019) Disinfection via Electrocoagulation Process: Implied Mechanisms and Future Tendencies. EC Microbiology, 15, 79-90.

[28] Ghernaout, D. and Elboughdiri, N. (2019) Mechanistic Insight into Disinfection Using Ferrate(VI). Open Access Library Journal, 6, e5946.

https://doi.org/10.4236/oalib.1105946

[29] Ghernaout, D. and Elboughdiri, N. (2019) Water Disinfection: Ferrate(VI) as the Greenest Chemical-A Review. Applied Engineering, 3, 171-180.

[30] Ghernaout, D. and Elboughdiri, N. (2020) Electrocoagulation Process in the Context of Disinfection Mechanism. Open Access Library Journal, 7, e6083.

[31] Ghernaout, D., Elboughdiri, N. and Ghareba, S. (2020) Fenton Technology for Wastewater Treatment: Dares and Trends. Open Access Library Journal, 7, e6045. https://doi.org/10.4236/oalib.1106045

[32] Boucherit, A., Moulay, S., Ghernaout, D., Al-Ghonamy, A.I., Ghernaout, B., Naceur, M.W., Ait Messaoudene, N., Aichouni, M., Mahjoubi, A.A. and Elboughdiri, N.A. (2015) New Trends in Disinfection By-Products Formation upon Water Treatment. Journal of Research \& Developments in Chemistry, 2015, Article ID: 628833.

[33] Ghernaout, D. and Elboughdiri, N. (2020) Strategies for Reducing Disinfection ByProducts Formation during Electrocoagulation. Open Access Library Journal, 7, e6076. https://doi.org/10.4236/oalib.1106076

[34] Ghernaout, D. and Elboughdiri, N. (2020) Disinfection By-Products: Presence and Elimination in Drinking Water. Open Access Library Journal, 7, e6140. https://doi.org/10.4236/oalib.1106140

[35] Ghernaout, D. and Elboughdiri, N. (2020) Controlling Disinfection By-Products Formation in Rainwater: Technologies and Trends. Open Access Library Journal, 7, e6162. https://doi.org/10.4236/oalib.1106162

[36] Rook, J.J. (1974) Formation of Haloforms during Chlorination of Nature Water. Water Treatment and Examination, 23, 234-243.

[37] Bellar, T.A., Lichtenberg, J.J. and Kroner, R.C. (1974) The Occurrence of Organohalides in Chlorinated Drinking Water. Journal of the American Water Works Association, 66, 703-706. https://doi.org/10.1002/j.1551-8833.1974.tb02129.x

[38] Boorman, G.A., Dellarco, V., Dunnick, J.K., Chapin, R.E., Hunter, S., Hauchman, F., Gardner, H., Cox, M. and Sills, R.C. (1999) Drinking Water Disinfection Byproducts: Review and Approach to Toxicity Evaluation. Environmental Health Perspectives, 107, 207-217. https://doi.org/10.2307/3434484

[39] Yu, Y. and Reckhow, D.A. (2017) Formation and Occurrence of N-chloro-2,2dichloroacetamide, a Previously Overlooked Nitrogenous Disinfection Byproduct in Chlorinated Drinking Waters. Environmental Science \& Technology, 51, 14881497. https://doi.org/10.1021/acs.est.6b04218 
[40] Ding, S.K., Chu, W.H., Bond, T., Wang, Q., Gao, N.Y., Xu, B. and Du, E.D. (2018) Formation and Estimated Toxicity of Trihalomethanes, Haloacetonitriles, and Haloacetamides from the Chlor(am)ination of Acetaminophen. Journal of Hazardous Materials, 341, 112-119. https://doi.org/10.1016/j.jhazmat.2017.07.049

[41] How, Z.T., Linge, K.L., Busetti, F. and Joll, C.A. (2017) Chlorination of Amino Acids: Reaction Pathways and Reaction Rates. Environmental Science \& Technology, 51, 4870-4876. https://doi.org/10.1021/acs.est.6b04440

[42] von Gunten, U. (2003) Ozonation of Drinking Water: Part II Disinfection and By-Product Formation in Presence of Bromide, Iodide or Chlorine. Water Research, 37, 1469-1487. https://doi.org/10.1016/S0043-1354(02)00458-X

[43] Lee, Y.G. and Jang, A. (2017) Application of Sensitive Electrochemical Sensing System for Detecting Bromate from Disinfection Process in Desalination Plant. Desalination, 423, 135-140. https://doi.org/10.1016/j.desal.2017.09.011

[44] Richardson, S.D., Thruston, A.D., Caughran, T.V., Chen, P.H., Collette, T.W., Schenck, K.M., Lykins, B.W., Rav-Acha, C. and Glezer, V. (2000) Identification of New Drinking Water Disinfection By-Products from Ozone, Chlorine Dioxide, Chloramine, and Chlorine. Water, Air, \& Soil Pollution, 123, 95-102. https://doi.org/10.1023/A:1005265509813

[45] Buchanan, W., Roddick, F. and Porter, N. (2006) Formation of Hazardous ByProducts Resulting from the Irradiation of Natural Organic Matter: Comparison between UV and VUV Irradiation. Chemosphere, 63, 1130-1141. https://doi.org/10.1016/j.chemosphere.2005.09.040

[46] Ghernaout, D., Naceur, M.W. and Ghernaout, B. (2011) A Review of Electrocoagulation as a Promising Coagulation Process for Improved Organic and Inorganic Matters Removal by Electrophoresis and Electroflotation. Desalination and Water Treatment, 28, 287-320. https://doi.org/10.5004/dwt.2011.1493

[47] Irki, S., Ghernaout, D., Naceur, M.W., Alghamdi, A. and Aichouni, M. (2018) Decolorizing Methyl Orange by Fe-Electrocoagulation Process-A Mechanistic Insight. International Journal of Environmental Chemistry, 2, 18-28. https://doi.org/10.11648/j.ijec.20180201.14

[48] Ghernaout, D. and Boucherit, A. (2015) Review of Coagulation's Rapid Mixing for NOM Removal. Journal of Research \& Developments in Chemistry, 2015, Article ID: 926518. https://doi.org/10.5171/2015.926518

[49] Ghernaout, D., Ghernaout, B. and Kellil, A. (2009) Natural Organic Matter Removal and Enhanced Coagulation as a Link between Coagulation and Electrocoagulation. Desalination and Water Treatment, 2, 203-222.

https://doi.org/10.5004/dwt.2009.116

[50] Ghernaout, D., Badis, A., Braikia, G., Matâam, N., Fekhar, M., Ghernaout, B. and Boucherit, A. (2017) Enhanced Coagulation for Algae Removal in a Typical Algeria Water Treatment Plant. Environmental Engineering and Management Journal, 16, 2303-2315. https://doi.org/10.30638/eemj.2017.238

[51] Djezzar, S., Ghernaout, D., Cherifi, H., Alghamdi, A., Ghernaout, B. and Aichouni, M. (2018) Conventional, Enhanced, and Alkaline Coagulation for Hard Ghrib Dam (Algeria) Water. World Journal of Applied Chemistry, 3, 41-55. https://doi.org/10.11648/j.wjac.20180302.12

[52] Kellali, Y. and Ghernaout, D. (2019) Physicochemical and Algal Study of Three Dams (Algeria) and Removal of Microalgae by Enhanced Coagulation. Applied Engineering, 3, 56-64.

[53] Ghernaout, D. and Ghernaout, B. (2012) Sweep Flocculation as a Second Form of 
Charge Neutralisation-A Review. Desalination and Water Treatment, 44, 15-28. https://doi.org/10.1080/19443994.2012.691699

[54] Ghernaout, D., Ghernaout, B., Saiba, A., Boucherit, A. and Kellil, A. (2009) Removal of Humic Acids by Continuous Electromagnetic Treatment Followed by Electrocoagulation in Batch Using Aluminium Electrodes. Desalination, 239, 295-308. https://doi.org/10.1016/j.desal.2008.04.001

[55] Ghernaout, D., Ghernaout, B., Boucherit, A., Naceur, M.W., Khelifa, A. and Kellil, A. (2009) Study on Mechanism of Electrocoagulation with Iron Electrodes in Idealised Conditions and Electrocoagulation of Humic Acids Solution in Batch Using Aluminium Electrodes. Desalination and Water Treatment, 8, 91-99. https://doi.org/10.5004/dwt.2009.668

[56] Ghernaout, D., Mariche, A., Ghernaout, B. and Kellil, A. (2010) Electromagnetic Treatment-Bi-Electrocoagulation of Humic Acid in Continuous Mode Using Response Surface Method for Its Optimization and Application on Two Surface Waters. Desalination and Water Treatment, 22, 311-329.

https://doi.org/10.5004/dwt.2010.1120

[57] Ghernaout, D., Irki, S. and Boucherit, A. (2014) Removal of $\mathrm{Cu}^{2+}$ and $\mathrm{Cd}^{2+}$, and Humic Acid and Phenol by Electrocoagulation Using Iron Electrodes. Desalination and Water Treatment, 52, 3256-3270. https://doi.org/10.1080/19443994.2013.852484

[58] Ghernaout, D., Al-Ghonamy, A.I., Naceur, M.W., Ait Messaoudene, N. and Aichouni, M. (2014) Influence of Operating Parameters on Electrocoagulation of C.I. Disperse Yellow 3. Journal of Electrochemical Science and Engineering, 4, 271-283. https://doi.org/10.5599/jese.2014.0065

[59] Ghernaout, D., Al-Ghonamy, A.I., Irki, S., Grini, A., Naceur, M.W., Ait Messaoudene, N. and Aichouni, M. (2014) Decolourization of Bromophenol Blue by Electrocoagulation Process. Trends in Chemical Engineering, 15, 29-39.

[60] Ghernaout, D., Al-Ghonamy, A.I., Ait Messaoudene, N., Aichouni, M., Naceur, M.W., Benchelighem, F.Z. and Boucherit, A. (2015) Electrocoagulation of Direct Brown 2 (DB) and BF Cibacete Blue (CB) Using Aluminum Electrodes. Separation Science and Technology, 50, 1413-1420. https://doi.org/10.1080/01496395.2014.982763

[61] Irki, S., Ghernaout, D. and Naceur, M.W. (2017) Decolourization of Methyl Orange (MO) by Electrocoagulation (EC) Using Iron Electrodes under a Magnetic Field (MF). Desalination and Water Treatment, 79, 368-377. https://doi.org/10.5004/dwt.2017.20797

[62] Irki, S., Ghernaout, D., Naceur, M.W., Alghamdi, A. and Aichouni, M. (2018) Decolorization of Methyl Orange (MO) by Electrocoagulation (EC) Using Iron Electrodes under a Magnetic Field (MF). II. Effect of Connection Mode. World Journal of Applied Chemistry, 3, 56-64. https://doi.org/10.11648/j.wjac.20180302.13

[63] Ghernaout, D. (2014) The Hydrophilic/Hydrophobic Ratio vs. Dissolved Organics Removal by Coagulation-A Review. Journal of King Saud University-Science, 26, 169-180. https://doi.org/10.1016/j.jksus.2013.09.005

[64] Ghernaout, D. (2013) Advanced Oxidation Phenomena in Electrocoagulation Process: A Myth or a Reality? Desalination and Water Treatment, 51, 7536-7554. https://doi.org/10.1080/19443994.2013.792520

[65] Ghernaout, D. and Elboughdiri, N. (2020) Advanced Oxidation Processes for Wastewater Treatment: Facts and Future Trends. Open Access Library Journal, 7, e6139. https://doi.org/10.4236/oalib.1106139 
[66] Ghernaout, D. and Naceur, M.W. (2011) Ferrate(VI): In Situ Generation and Water Treatment-A Review. Desalination and Water Treatment, 30, 319-332. https://doi.org/10.5004/dwt.2011.2217

[67] Ghernaout, D. (2019) Reviviscence of Biological Wastewater Treatment-A Review. Applied Engineering, 3, 46-55.

[68] Al Arni, S., Amous, J. and Ghernaout, D. (2019) On the Perspective of Applying of a New Method for Wastewater Treatment Technology: Modification of the Third Traditional Stage with Two Units, One by Cultivating Microalgae and Another by Solar Vaporization. International Journal of Environmental Sciences \& Natural Resources, 16, Article ID: 555934. https://doi.org/10.19080/IJESNR.2019.16.555934

[69] Ghernaout, D., Elboughdiri, N. and Al Arni, S. (2019) Water Reuse (WR): Dares, Restrictions, and Trends. Applied Engineering, 3, 159-170.

[70] Ghernaout, D. (2013) The Best Available Technology of Water/Wastewater Treatment and Seawater Desalination: Simulation of the Open Sky Seawater Distillation. Green and Sustainable Chemistry, 3, 68-88. https://doi.org/10.4236/gsc.2013.32012

[71] Ghernaout, D. and Elboughdiri, N. (2020) Eliminating Cyanobacteria and Controlling Algal Organic Matter-Short Notes. Open Access Library Journal, 7, e6252. https://doi.org/10.4236/oalib.1106252

[72] Ghernaout, D., Elboughdiri, N., Ghareba, S. and Salih, A. (2020) Coagulation Process for Removing Algae and Algal Organic Matter-An Overview. Open Access Library Journal, 7, e6272. https://doi.org/10.4236/oalib.1106272

[73] Ghernaout, B., Ghernaout, D. and Saiba, A. (2010) Algae and Cyanotoxins Removal by Coagulation/Flocculation: A Review. Desalination and Water Treatment, 20, 133-143. https://doi.org/10.5004/dwt.2010.1202

[74] Ghernaout, D. and Ghernaout, B. (2012) On the Concept of the Future Drinking Water Treatment Plant: Algae Harvesting from the Algal Biomass for Biodiesel Production-A Review. Desalination and Water Treatment, 49, 1-18. https://doi.org/10.1080/19443994.2012.708191

[75] Ghernaout, D., Benblidia, C. and Khemici, F. (2015) Microalgae Removal from Ghrib Dam (Ain Defla, Algeria) Water by Electroflotation Using Stainless Steel Electrodes. Desalination and Water Treatment, 54, 3328-3337. https://doi.org/10.1080/19443994.2014.907749

[76] Ghernaout, D. (2019) Electrocoagulation Process for Microalgal Biotechnology-A Review. Applied Engineering, 3, 85-94.

[77] Ghernaout, D., Badis, A., Ghernaout, B. and Kellil, A. (2008) Application of Electrocoagulation in Escherichia coli Culture and Two Surface Waters. Desalination, 219, 118-125. https://doi.org/10.1016/j.desal.2007.05.010

[78] Ghernaout, D., Al-Ghonamy, A.I., Boucherit, A., Ghernaout, B., Naceur, M.W., Ait Messaoudene, N., Aichouni, M., Mahjoubi, A.A. and Elboughdiri, N.A. (2015) Brownian Motion and Coagulation Process. American Journal of Environmental Protection, 4, 1-15.

[79] Ghernaout, D., Al-Ghonamy, A.I., Naceur, M.W., Boucherit, A., Messaoudene, N.A., Aichouni, M., Mahjoubi, A.A. and Elboughdiri, N.A. (2015) Controlling Coagulation Process: From Zeta Potential to Streaming Potential. American Journal of Environmental Protection, 4, 16-27. https://doi.org/10.11648/j.ajeps.s.2015040501.12

[80] Ghernaout, D. (2017) Entropy in the Brownian Motion (BM) and Coagulation Background. Colloid and Surface Science, 2, 143-161.

[81] Ghernaout, D., Simoussa, A., Alghamdi, A., Ghernaout, B., Elboughdiri, N., Mah- 
joubi, A., Aichouni, M. and El-Wakil, A.E.A. (2018) Combining Lime Softening with Alum Coagulation for Hard Ghrib Dam Water Conventional Treatment. International Journal of Advances in Applied Sciences, 5, 61-70. https://doi.org/10.21833/ijaas.2018.05.008

[82] Ghernaout, D. and El-Wakil, A. (2017) Requiring Reverse Osmosis Membranes Modifications-An Overview. American Journal of Chemical Engineering, 5, 81-88. https://doi.org/10.11648/j.ajche.20170504.15

[83] Ghernaout, D. (2017) Reverse Osmosis Process Membranes Modeling-A Historical Overview. Journal of Civil, Construction and Environmental Engineering, 2, 112-122.

[84] Ghernaout, D., El-Wakil, A., Alghamdi, A., Elboughdiri, N. and Mahjoubi, A. (2018) Membrane Post-Synthesis Modifications and How It Came about. International Journal of Advances in Applied Sciences, 5, 60-64.

https://doi.org/10.21833/ijaas.2018.02.010

[85] Ghernaout, D., Alshammari, Y., Alghamdi, A., Aichouni, M., Touahmia, M. and Ait Messaoudene, N. (2018) Water Reuse: Extenuating Membrane Fouling in Membrane Processes. International Journal of Environmental Chemistry, 2, 1-12. https://doi.org/10.11648/j.ajche.20180602.12

[86] Ghernaout, D. (2019) Brine Recycling: Towards Membrane Processes as the Best Available Technology. Applied Engineering, 3, 71-84.

[87] Ait Messaoudene, N., Naceur, M.W., Ghernaout, D., Alghamdi, A. and Aichouni, M. (2018) On the Validation Perspectives of the Proposed Novel Dimensionless Fouling Index. International Journal of Advances in Applied Sciences, 5, 116-122.

[88] Ghernaout, D. and Elboughdiri, N. (2019) Water Reuse: Emerging Contaminants Elimination-Progress and Trends. Open Access Library Journal, 6, e5981. https://doi.org/10.4236/oalib.1105981

[89] Ghernaout, D. and Elboughdiri, N. (2020) Domestic Wastewater Treatment: Difficulties and Reasons, and Prospective Solutions-China as an Example. Open Access Library Journal, 7, e6141.

[90] Ghernaout, D. (2018) Increasing Trends towards Drinking Water Reclamation from Treated Wastewater. World Journal of Applied Chemistry, 3, 1-9. https://doi.org/10.11648/j.wjac.20180301.11

[91] Ghernaout, D., Alshammari, Y. and Alghamdi, A. (2018) Improving Energetically Operational Procedures in Wastewater Treatment Plants. International Journal of Advances in Applied Sciences, 5, 64-72. https://doi.org/10.21833/ijaas.2018.09.010

[92] Ghernaout, D. and Elboughdiri, N. (2019) Upgrading Wastewater Treatment Plant to Obtain Drinking Water. Open Access Library Journal, 6, e5959. https://doi.org/10.4236/oalib.1105959

[93] Shen, R. and Andrews, S.A. (2011) Demonstration of 20 Pharmaceuticals and Personal Care Products (PPCPs) as Nitrosamine Precursors during Chloramine Disinfection. Water Research, 45, 944-952. https://doi.org/10.1016/j.watres.2010.09.036

[94] Ghernaout, D. (2017) Water Reuse (WR): The Ultimate and Vital Solution for Water Supply Issues. International Journal of Sustainable Development Research, 3, 36-46. https://doi.org/10.11648/j.ijsdr.20170304.12

[95] Ghernaout, D., Elboughdiri, N. and Ghareba, S. (2019) Drinking Water Reuse: One-Step Closer to Overpassing the "Yuck Factor". Open Access Library Journal, 6, e5895. https://doi.org/10.4236/oalib.1105895

[96] Ghernaout, D., Elboughdiri, N. and Alghamdi, A. (2019) Direct Potable Reuse: The 
Singapore NEWater Project as a Role Model. Open Access Library Journal, 6, e5980. https://doi.org/10.4236/oalib.1105980

[97] Ghernaout, D. and Elboughdiri, N. (2020) Magnetic Field Application: An Underappreciated Outstanding Technology. Open Access Library Journal, 7, e6000.

[98] Ghernaout, D. (2018) Magnetic Field Generation in the Water Treatment Perspectives: An Overview. International Journal of Advances in Applied Sciences, 5, 193203. https://doi.org/10.21833/ijaas.2018.01.025

[99] Uyak, V. and Toroz, I. (2007) Investigation of Bromide Ion Effects on Disinfection By-Products Formation and Speciation in an Istanbul Water Supply. Journal of Hazardous Materials, 149, 445-451. https://doi.org/10.1016/j.jhazmat.2007.04.017

[100] Mao, Y.Q., Wang, X.M., Yang, H.W., Wang, H.Y. and Xie, Y.F.F. (2014) Effects of Ozonation on Disinfection Byproduct Formation and Speciation during Subsequent Chlorination. Chemosphere, 117, 515-520. https://doi.org/10.1016/j.chemosphere.2014.08.083

[101] Dong, H.Y., Qjang, Z.M. and Richardson, S.D. (2019) Formation of Iodinated Disinfection Byproducts (I-DBPs) in Drinking Water: Emerging Concerns and Current Issues. Accounts of Chemical Research, 52, 896-905. https://doi.org/10.1021/acs.accounts.8b00641

[102] Krasner, S.W., Weinberg, H.S., Richardson, S.D., Pastor, S.J., Chinn, R., Sclimenti, M.J., Onstad, G.D. and Thruston Jr., A.D. (2006) Occurrence of a New Generation of Disinfection Byproducts. Environmental Science \& Technology, 40, 7175-7185. https://doi.org/10.1021/es060353j

[103] Bougeard, C.M.M., Goslan, E.H., Jefferson, B. and Parsons, S.A. (2010) Comparison of the Disinfection By-Product Formation Potential of Treated Waters Exposed to Chlorine and Monochloramine. Water Research, 44, 729-740. https://doi.org/10.1016/j.watres.2009.10.008

[104] Shen, R.Q. and Andrews, S.A. (2011) NDMA Formation Kinetics from Three Pharmaceuticals in Four Water Matrices. Water Research, 45, 5687-5694. https://doi.org/10.1016/j.watres.2011.08.034

[105] Zhai, H., He, X., Zhang, Y., Du, T., Adeleye, A.S. and Li, Y. (2017) Disinfection Byproduct Formation in Drinking Water Sources: A Case Study of Yuqiao Reservoir. Chemosphere, 181, 224-231. https://doi.org/10.1016/j.chemosphere.2017.04.028

[106] Velleitner, N.K., Delaat, J., Dore, M., Suty, H. and Pouillot, M. (1992) Chlorite and Chlorine Dioxide Removal by Activated Carbon. Water Research, 26, 1053-1066. https://doi.org/10.1016/0043-1354(92)90141-P

[107] Al-Otoum, F., Al-Ghouti, M.A., Ahmed, T.A., Abu-Dieyeh, M. and Ali, M. (2016) Disinfection Byproducts of Chlorine Dioxide (Chlorite, Chlorate, and Trihalomethanes): Occurrence in Drinking Water in Qatar. Chemosphere, 164, 649-656. https://doi.org/10.1016/j.chemosphere.2016.09.008

[108] Gan, W.H., Huang, H., Yang, X., Peng, Z.R. and Chen, G.H. (2016) Emerging Investigators Series: Disinfection By-Products in Mixed Chlorine Dioxide and Chlorine Water Treatment. Environmental Science: Water Research \& Technology, 2, 838-847. https://doi.org/10.1039/C6EW00061D

[109] Qi, W., Hua, Z., Hu, C., Liu, H. and Qu, J. (2017) Effect of Ozonation on the Characteristics of Effluent Organic Matter Fractions and Subsequent Associations with Disinfection Byproducts Formation. Science of the Total Environment, 610, 10571064. https://doi.org/10.1016/j.scitotenv.2017.08.194

[110] Zeng, T., Plewa, M.J. and Mitch, W.A. (2016) N-Nitrosamines and Halogenated Disinfection Byproducts in US Full Advanced Treatment Trains for Potable Reuse. 
Water Research, 101, 176-186. https://doi.org/10.1016/j.watres.2016.03.062

[111] Zheng, J., Lin, T., Chen, W., Tao, H., Tan, Y. and Ma, B. (2018) Removal of Precursors of Typical Nitrogenous Disinfection Byproducts in Ozonation Integrated with Biological Activated Carbon $\left(\mathrm{O}_{3} / \mathrm{BAC}\right)$. Chemosphere, 209, 68-77. https://doi.org/10.1016/j.chemosphere.2018.06.018

[112] Ghernaout, D., Ghernaout, B. and Naceur, M.W. (2011) Embodying the Chemical Water Treatment in the Green Chemistry-A Review. Desalination, 271, 1-10. https://doi.org/10.1016/j.desal.2011.01.032

[113] Uyak, V. and Toroz, L. (2005) Enhanced Coagulation of Disinfection By-Products Precursors in Istanbul Water Supply. Environmental Technology, 26, 261-266. https://doi.org/10.1080/09593332608618567

[114] Ghernaout, D., Aichouni, M. and Alghamdi, A. (2018) Applying Big Data (BD) in Water Treatment Industry: A New Era of Advance. International Journal of Advances in Applied Sciences, 5, 89-97. https://doi.org/10.21833/ijaas.2018.03.013

[115] Alshammari, Y., Ghernaout, D., Aichouni, M. and Touahmia, M. (2018) Improving Operational Procedures in Riyadh's (Saudi Arabia) Water Treatment Plants Using Quality Tools. Applied Engineering, 2, 60-71.

[116] Ghernaout, D., Laribi, C., Alghamdi, A., Ghernaout, B., Ait Messaoudene, N. and Aichouni, M. (2018) Decolorization of BF Cibacete Blue (CB) and Red Solophenyle 3BL (RS) Using Aluminum Sulfate and Ferric Chloride. World Journal of Applied Chemistry, 3, 32-40. https://doi.org/10.11648/j.wjac.20180302.11

[117] Ghernaout, D., Alghamdi, A. and Ghernaout, B. (2019) Electrocoagulation Process: A Mechanistic Review at the Dawn of Its Modeling. Journal of Environmental Science and Allied Research, 2, 51-67. https://doi.org/10.29199/2637-7063/ESAR-201019

[118] Ghernaout, D. (2019) Virus Removal by Electrocoagulation and Electrooxidation: New Findings and Future Trends. Journal of Environmental Science and Allied Research, 85-90. https://doi.org/10.29199/2637-7063/ESAR-202024

[119] Ghernaout, D., Ghernaout, B. and Boucherit, A. (2008) Effect of pH on Electrocoagulation of Bentonite Suspensions in Batch Using Iron Electrodes. Journal of Dispersion Science and Technology, 29, 1272-1275. https://doi.org/10.1080/01932690701857483

[120] Belhout, D., Ghernaout, D., Djezzar-Douakh, S. and Kellil, A. (2010) Electrocoagulation of a Raw Water of Ghrib Dam (Algeria) in Batch Using Iron Electrodes. Desalination and Water Treatment, 16, 1-9. https://doi.org/10.5004/dwt.2010.1081

[121] Ghernaout, D. and Ghernaout, B. (2011) On the Controversial Effect of Sodium Sulphate as Supporting Electrolyte on Electrocoagulation Process: A Review. Desalination and Water Treatment, 27, 243-254. https://doi.org/10.5004/dwt.2011.1983

[122] Ghernaout, D. (2018) Electrocoagulation Process: Achievements and Green Perspectives. Colloid and Surface Science, 3, 1-5. https://doi.org/10.11648/j.css.20180301.11

[123] Ghernaout, D. and Elboughdiri, N. (2020) An Insight in Electrocoagulation Process through Current Density Distribution (CDD). Open Access Library Journal, 7, e6142.

[124] Kim, M.H. and Yu, M.J. (2005) Characterization of NOM in the Han River and Evaluation of Treatability Using UF-NF Membrane. Environmental Research, 97, 116-123. https://doi.org/10.1016/j.envres.2004.07.012

[125] Zhou, C., Gao, N.Y., Deng, Y., Chu, W.H., Rong, W.L. and Zhou, S.D. (2012) Factors Affecting Ultraviolet Irradiation/Hydrogen Peroxide $\left(\mathrm{UV} / \mathrm{H}_{2} \mathrm{O}_{2}\right)$ Degradation 
of Mixed N-Nitrosamines in Water. Journal of Hazardous Materials, 231, 43-48. https://doi.org/10.1016/j.jhazmat.2012.06.032

[126] Chu, W.H., Gao, N.Y. and Deng, Y. (2009) Performance of a Combination Process of $\mathrm{UV} / \mathrm{H}_{2} \mathrm{O}_{2} /$ Micro-Aeration for Oxidation of Dichloroacetic Acid in Drinking Water. Clean-Soil Air Water, 37, 233-238. https://doi.org/10.1002/clen.200900002

[127] Penders, E.J.M., Martijn, A.J., Spenkelink, A., Alink, G.M., Rietjens, I. and Hoogenboezem, W. (2012) Genotoxicity Testing of Samples Generated during UV/ $\mathrm{H}_{2} \mathrm{O}_{2}$ Treatment of Surface Water for the Production of Drinking Water Using the Ames Test in Vitro and the Comet Assay and the SCE Test in Vivo. Journal of Water Supply: Research and Technology-AQUA, 61, 435-445. https://doi.org/10.2166/aqua.2012.069

[128] Ghernaout, D., Alghamdi, A., Touahmia, M., Aichouni, M. and Ait Messaoudene, N. (2018) Nanotechnology Phenomena in the Light of the Solar Energy. Journal of Energy, Environmental \& Chemical Engineering, 3, 1-8. https://doi.org/10.11648/j.jeece.20180301.11

[129] Ghernaout, D. and Elboughdiri, N. (2020) Environmental Engineering for Stopping Viruses Pandemics. Open Access Library Journal, 7, e6299.

[130] Saiba, A., Kourdali, S., Ghernaout, B. and Ghernaout, D. (2010) In Desalination, from 1987 to 2009, the Birth of a New Seawater Pretreatment Process: Electrocoagulation-An Overview. Desalination and Water Treatment, 16, 201-217. https://doi.org/10.5004/dwt.2010.1094

[131] Ghernaout, D., Elboughdiri, N. and Ghernaout, B. (2020) Trends in Decreasing Disinfection By-Products Formation during Electrochemical Technologies. Open Access Library Journal, 7, e6142.

[132] Ghernaout, D. (2019) Greening Cold Fusion as an Energy Source for Water Treatment Distillation-A Perspective. American Journal of Quantum Chemistry and Molecular Spectroscopy, 3, 1-5. 